\title{
Synthesis, characterization and evaluation of antifungal activity of seven-membered heterocycles
}

\author{
Rasim Farraj Muslim" ${ }^{1 *}$ Hiba Mahir Tawfeeq ${ }^{2}$, Mustafa Nadhim Owaid ${ }^{3}$ Obaid Hasan Abid ${ }^{4}$ \\ 'Department of Ecology, College of Applied Sciences, University of Anbar, Hit 31007, Anbar, Iraq \\ ${ }^{2}$ Department of Chemistry, College of Education for Pure Sciences, Ramadi 31001, University of Anbar, Anbar, Iraq \\ ${ }^{3}$ Department of Heet Education, General Directorate of Education in Anbar, Ministry of Education, Hit, Anbar 31007, Iraq \\ ${ }^{4}$ Department of Scientific Affairs and Graduate Studies, University of Fallujah, Anbar, Iraq
}

\begin{abstract}
This research includes synthesis of new heterocyclic derivatives of disubstituted 1,3-oxazepine-5-one. Azomethine compounds (N1-N5) were synthesized by the reaction of aromatic aldehydes with primary aromatic amines, in the presence of glacial acetic acid as a catalyst in absolute ethanol. The synthesized compounds were identified via spectral methods viz., FT-IR, $1 \mathrm{H}-\mathrm{NMR}$, and $13 \mathrm{C}-\mathrm{NMR}$ and measurements of some physical properties. The prepared oxazepine compounds (N6-N10) were obtained from treatment of azomethine compounds with phthalide. N9 and $\mathrm{N} 7$ derivatives have recorded the higher zone of inhibition $15 \mathrm{~mm}$ against Candida guilliermondii and Candida zeylanoides respectively. The lower zone of inhibition was $8.0 \mathrm{~mm}$ and $9.3 \mathrm{~mm}$ by $\mathrm{N} 7$ toward the growth of Candida albicans and Candida guilliermondii respectively. Slight variation in the structure of those derivatives can show the very dramatic effect on the efficiency of these compounds in their bio-activity and may be helpful in designing more antifungal agents for therapeutic use in future.
\end{abstract}

Keywords: Azomethine, anti-candidal activity, NMR, phthalide, oxazepine.

\section{INTRODUCTION}

Azomethine compounds are class of compounds containing the group $(\mathrm{C}=\mathrm{N})$ (Scheme 1), usually prepared by the condensation of a primary aromatic amino group with an active carbonyl aromatic aldehyde. They are versatile precursors in the synthesis of organic, bio-organic, organometallic and industrial compounds via ring closure, cycloaddition, and replacement reactions. ${ }^{1-3}$

*Corresponding author: Rasim Farraj Muslim, e-mail: dr.rasim92hmts@gmail.com (Received 13 February 2018, accepted 03 March 2018) 
A German chemist discovered azomethine compounds, Nobel Prize winner, Hugo Schiff in $1864^{4}$, and structurally, an analog of a ketone or aldehyde in which azomethine group has replaced the carbonyl group $(\mathrm{C}=\mathrm{O})$, as shown in Scheme $1 .^{5}$

$$
\mathbf{R}=\mathbf{H}
$$

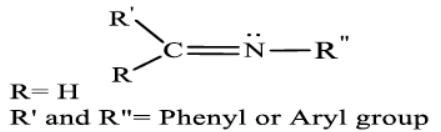

Structure of Azomethine Compounds

Scheme 1. Structure of azomethine compounds

Initially, the classical synthetic route for azomethine compounds involves condensation of ammonia, primary amines and amino acids with carbonyl compounds under azeotropic distillation with the simultaneous removal of water ${ }^{6-8}$, see Scheme 2.

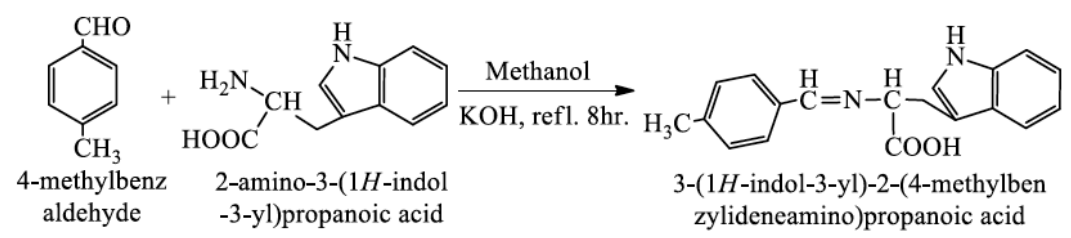

Scheme 2. The effect of $\mathrm{KOH}$ on azomethine synthesis

The reaction of pyridine-2-amine with 4-(dimethyl amino) benzaldehyde produces the azomethine compound (Scheme 3$).{ }^{9}$

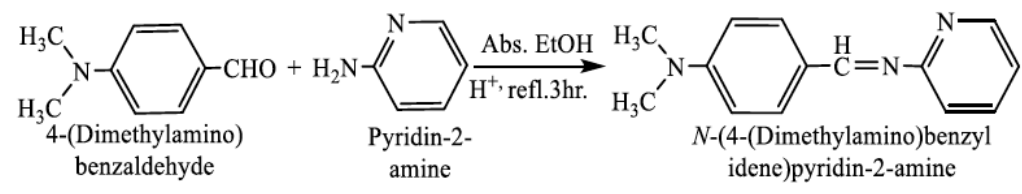

Scheme 3 The prepared azomethine compound presence glacial acetic acid

Oxazepines are class of heterocyclic compounds of the seven-membered ring with two heteroatoms ( $\mathrm{O}$ and $\mathrm{N}$ ). The oxygen atom is located at position 1 and a nitrogen atom in positions -2,-3 or -4. Example of one of oxazepine compound is the product of the reaction between azomethine compounds and pyromellitic dianhydride (Scheme 4). ${ }^{10}$ 

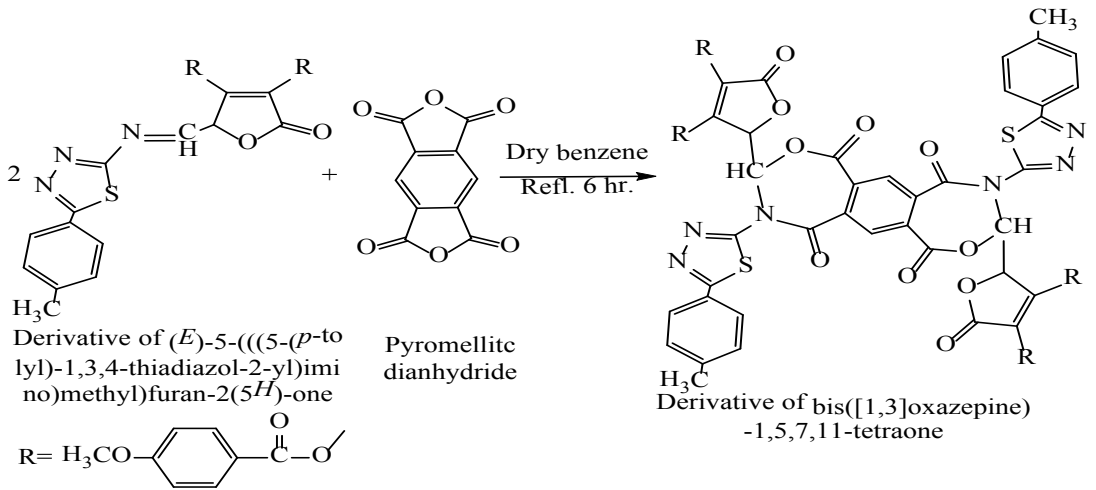

Scheme 4 Using dry benzene as a solvent to prepare oxazepine derivatives

Reaction of azomethine compound (2-Amino-1,3,4 -thiadiazole-5-thiol) with 3-Nitrophthalic anhydride gave oxazepine compounds in efficient yields, see Scheme $5 \cdot{ }^{11}$

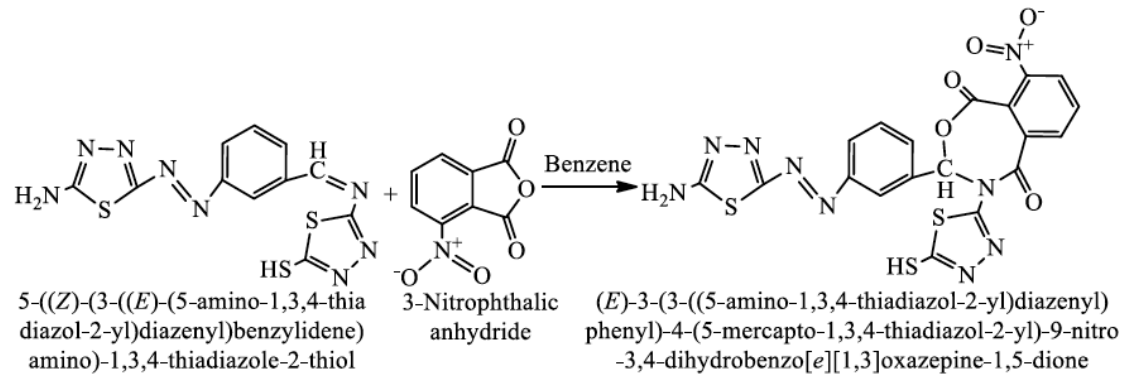

Scheme 5 Effect of nitro group on product efficiency of the prepared oxazepine compound

The aim of this work is preparing azomethine compounds from aromatic aldehyde reaction with primary aromatic amines to interfere with the preparation of oxazepine compounds from the reaction of azomethine compounds prepared with phthalide compound. Oxazepine compounds were tested against some pathogenic yeasts in vitro.

\section{METHODOLOGY}

Melting points were recorded on Electrothermal Melting point Apparatus (uncorrected). FT-IR spectra were recorded at room temperature from 4000-400 $\mathrm{cm}^{-1}$ with $\mathrm{KBr}$ disc on Infrared Spectrophotometer Model Tensor 27 Bruker Co., Germany. The ${ }^{1} \mathrm{H}-\mathrm{NMR}$ and ${ }^{13} \mathrm{C}-\mathrm{NMR}$ spectra were recorded on Bruker Ac30oMHz spectrometer. 


\section{General Procedure for synthesis of azomethine compounds $\mathbf{N}_{1}-\mathbf{N}_{5}$}

Equimolar mixtures $0.02 \mathrm{~mol}$ of aldehydes and aromatic amines and trace of glacial acetic acid dissolved in $25 \mathrm{ml}$ absolute ethanol was placed in a 100-ml round-bottom flask equipped with condenser and stirrer bar. The mixture was allowed to react at reflux temperature for 4 hour, and then let to cool down to the room temperature, whereby a crystalline solid was separated out. The solid product was recrystallized twice from ethanol. The structural formula, names, melting points, colors, and percentage of yields for the synthesized azomethine compounds are recorded. ${ }^{12-19}$

\section{General procedure for synthesis of oxazepine compounds $N_{6}-N_{10}$}

Equimolar mixtures $0.01 \mathrm{~mol}$ of azomethine compounds and phthalide compound dissolved in $30 \mathrm{ml}$ of tetrahydrofuran was placed in a 100-ml roundbottom flask equipped with condenser and stirrer bar presence trace of glacial acetic acid as a catalyst was added. The reaction mixture was refluxed for 3 hour, and left to stand for 24 hour and then solid product was precipitated. The solid product was filtered off and recrystallized from ethanol. The structural formula, names, melting points, colors, and percentage of yields for the prepared oxazepine compounds are recorded. ${ }^{20-25}$

\section{Antifungal activity}

This test was archived in vitro to investigate inhibitory effects of the prepared oxazepine compounds using well diffusion method on Muller-Hinton agar. This experiment was done as mentioned by Owaid et al. Four milligrams of the prepared oxazepine compounds were dissolved in absolute methanol and applied separately in $6 \mathrm{~mm}$-well, while methanol was used as a control. ${ }^{26}$ After $18 \mathrm{hr}$ of incubation at $37^{\circ} \mathrm{C}$, the zone of inhibition was taken using the ruler in millimeters.

\section{RESULTS AND DISCUSSION}

Tables 1 and 2 exhibited structural formula, nomenclature, the percentage of yield, melting point, and their color. The best yield of the prepared azomethine compounds was $90 \%$ for compounds $\mathrm{N}_{3}$ and $\mathrm{N}_{4}$ while the lower yield was $80 \%$ for compounds $\mathrm{N}_{2}$. The higher melting point was $250-252{ }^{\circ} \mathrm{C}$ for compound $\mathrm{N}_{2}$. The lower melting point was $60-62{ }^{\circ} \mathrm{C}$ for compound $\mathrm{N}_{1}$. The best yield of the prepared oxazepine compounds was $91 \%$ for compounds $\mathrm{N}_{9}$ while $\mathrm{N}_{8}$ compound given lower yield reaches $75 \%$. The higher melting point was $243-245{ }^{\circ} \mathrm{C}$ for compound $\mathrm{N}_{8}$. The lower melting point was $76-78{ }^{\circ} \mathrm{C}$ for compound $\mathrm{N}_{6}$. The different colors and melting points between the raw material and products are initial evidence to take place the chemical reaction. 


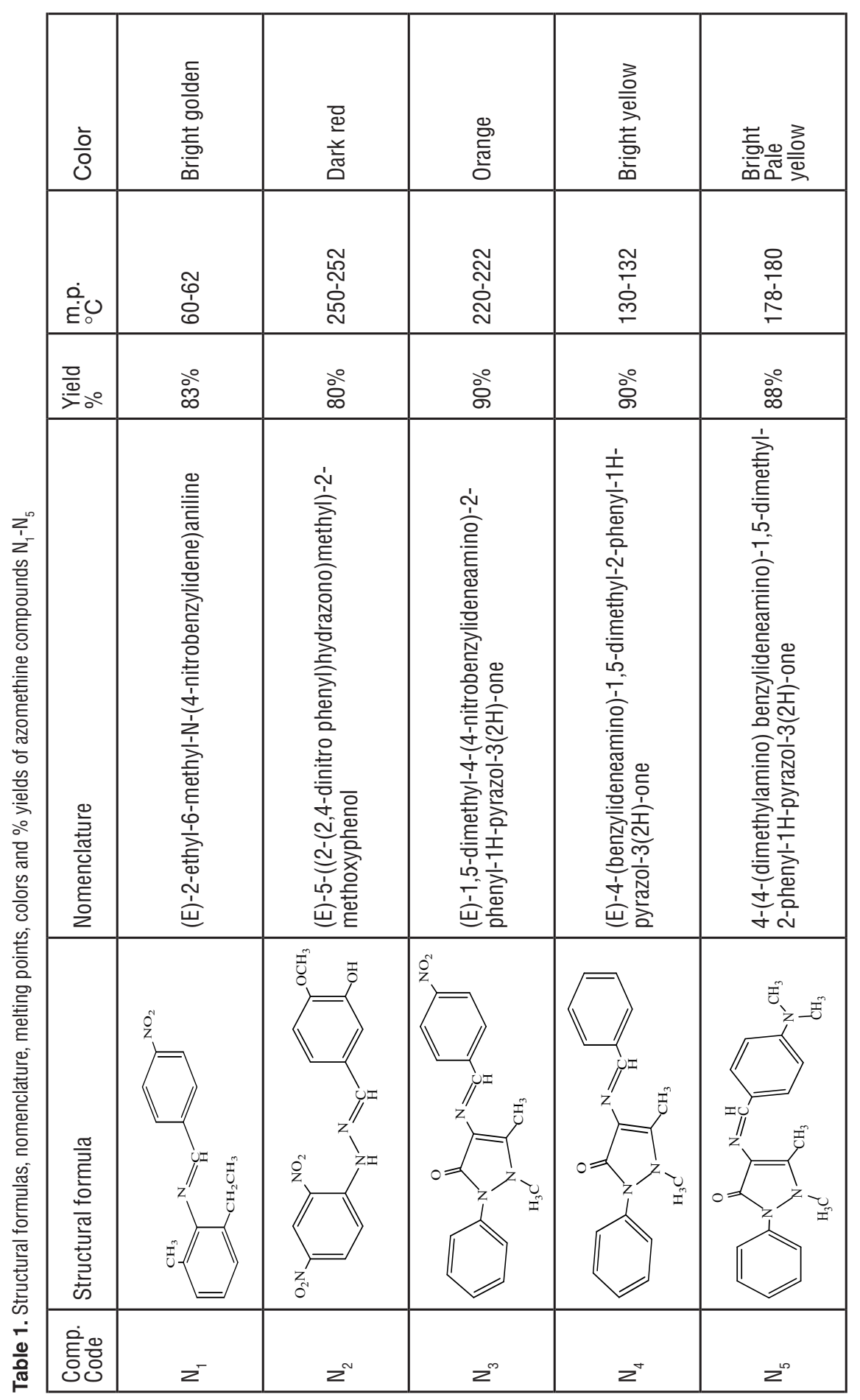




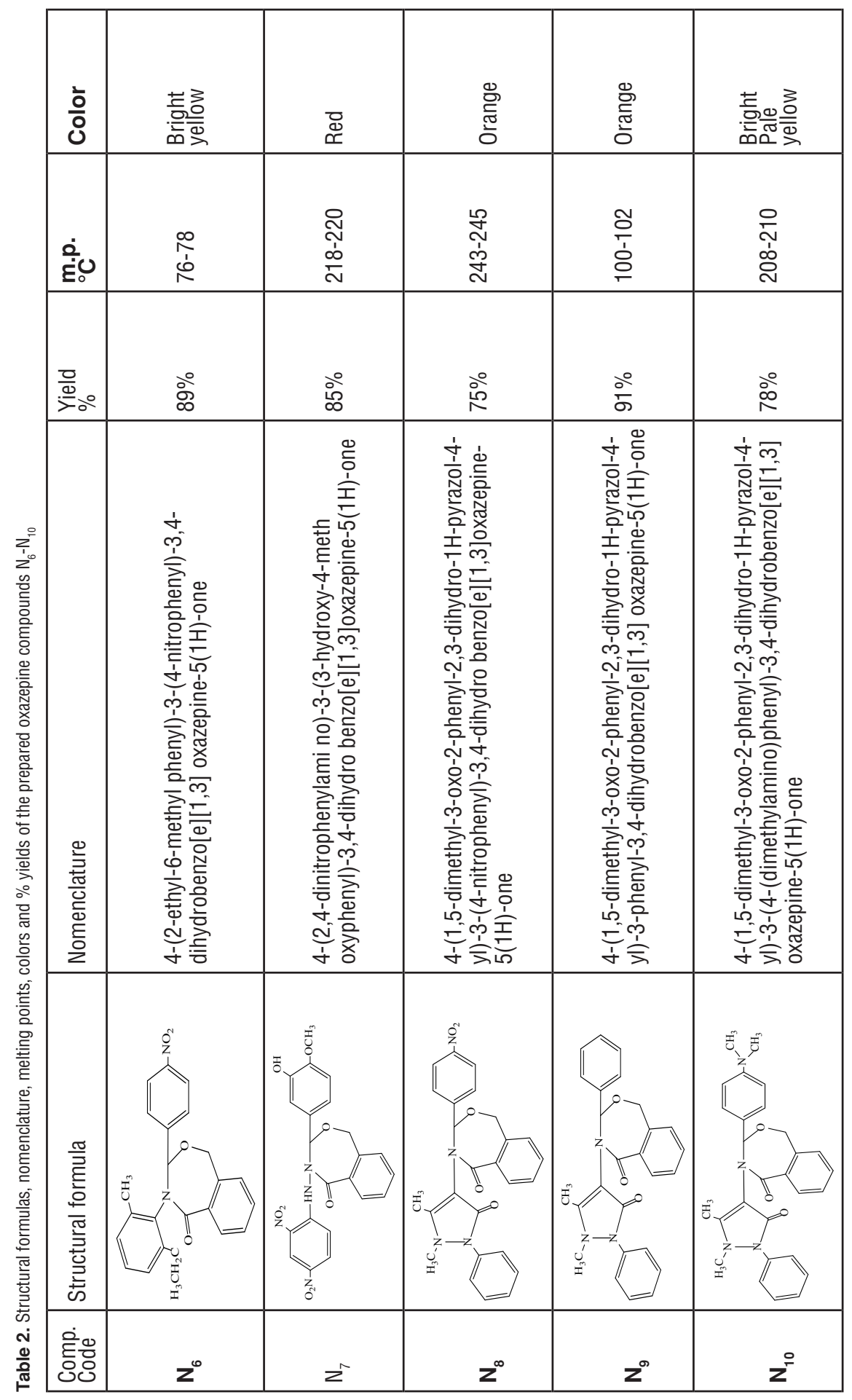


Azomethine compounds were synthesized from commercially available aromatic aldehydes and primary aromatic amines and identified by their melting points and FT-IR.

FT-IR spectra showed the disappearance of the stretching absorption bands of carbonyl group $(\mathrm{C}=\mathrm{O})$ of the aldehydes at $1700-1715 \mathrm{~cm}^{-1}$ and the appearance of the stretching absorption bands of azomethine group $(\mathrm{C}=\mathrm{N})$ at $1549-1642$ $\mathrm{cm}^{-1}$ indicative of the formation of the resulting imines beside the characteristic bands of the residual groups in the structure (Scheme 6). It was observed that the aromatic amine which contains electrophoresis group in at para position when condensing with aromatic aldehyde; it has less reaction speed. While the reaction speed increases when the same group and the same site on the aromatic aldehyde ring. Glacial acid is used as a catalyst to increase the electrophile of the carbonyl group to accelerate the reaction and increase the precentage yield, see Table 3 and Figures 1 and $2 .{ }^{27}$

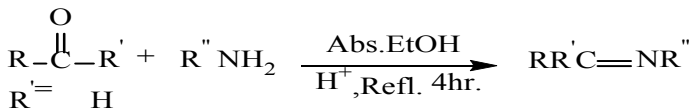

$$
\begin{aligned}
& R=
\end{aligned}
$$

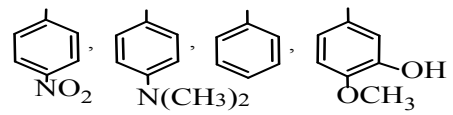

$$
\begin{aligned}
& \mathrm{R}=\overbrace{\mathrm{CH}_{3}}^{\mathrm{C}_{2} \mathrm{H}_{5}}, \underbrace{\mathrm{NH}}_{\mathrm{NO}_{2}} \overbrace{\mathrm{C}_{3} \mathrm{C}_{\mathrm{C}_{3}}}^{\mathrm{NO}_{2}}
\end{aligned}
$$

Scheme 6. Structure of the prepared azomethine compounds

Table 3. FTIR of azomethine compounds $\mathrm{N}_{1}-\mathrm{N}_{5}$

\begin{tabular}{|c|c|c|c|c|c|c|c|}
\hline \multicolumn{8}{|c|}{ FT-IR, $n\left(\mathrm{~cm}^{-1}\right)$} \\
\hline \multirow{2}{*}{$\begin{array}{l}\text { Comp. } \\
\text { Code }\end{array}$} & \multirow{2}{*}{$\mathrm{C}=\mathrm{N}$} & \multirow{2}{*}{$\begin{array}{c}\mathrm{C}=\mathrm{C} \\
\text { Aromatic }\end{array}$} & \multicolumn{2}{|c|}{$\mathrm{C}-\mathrm{H}$} & \multicolumn{2}{|c|}{ C-H Ali. } & \multirow{2}{*}{ Others } \\
\hline & & & Aromatic & Alkene & Asym. & sym. & \\
\hline$N_{1}$ & 1642 & 1599 & 3066 & 3101 & 2963 & 2874 & $\mathrm{NO}_{2} 1519,1341$ \\
\hline $\mathrm{N}_{2}$ & 1609 & 1580 & 3042 & 3113 & 2972 & 2945 & $\begin{array}{c}\mathrm{NO}_{2} 1500,1328 \\
0-\mathrm{H} 3491, \mathrm{NH} 3278\end{array}$ \\
\hline $\mathrm{N}_{3}$ & 1549 & 1481 & 3043 & 3070 & 2962 & 2886 & $\begin{array}{c}\mathrm{C}=01640 \\
\mathrm{NO}_{2} 1511,1334\end{array}$ \\
\hline $\mathrm{N}_{4}$ & 1592 & 1562 & 3042 & 3088 & 2984 & 2874 & $C=01645$ \\
\hline $\mathrm{N}_{5}$ & 1607 & 1580 & 3042 & 3101 & 2987 & 2891 & $\mathrm{C}=01642$ \\
\hline
\end{tabular}




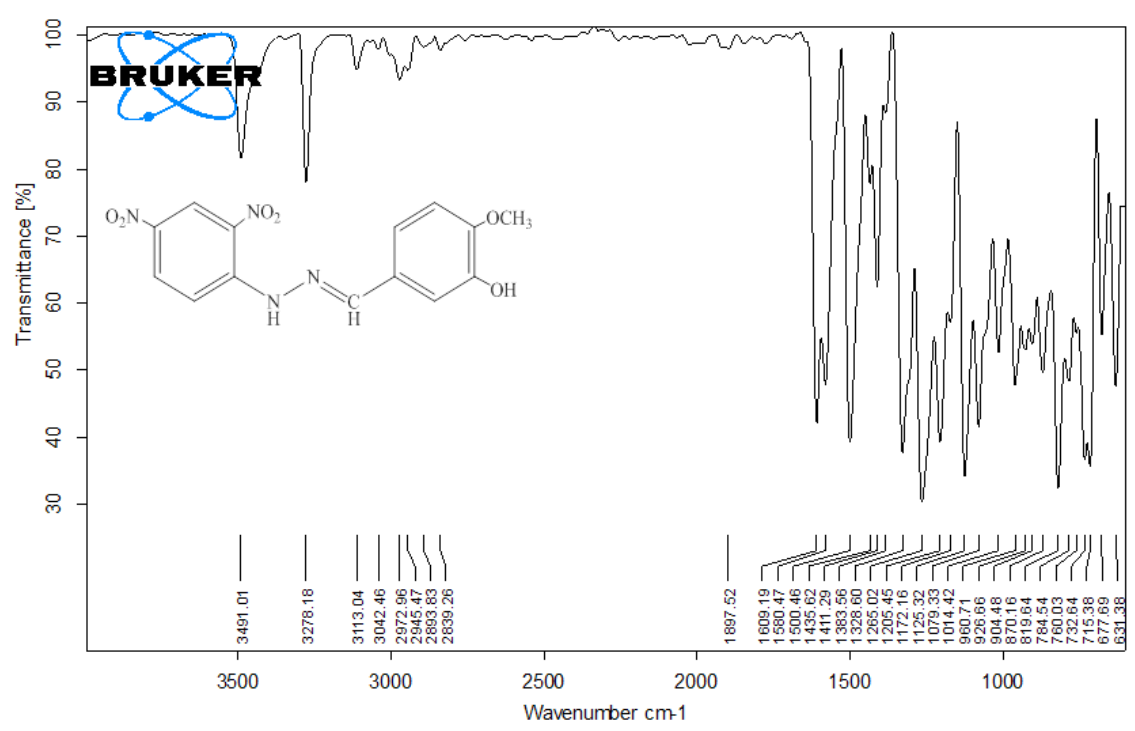

Figure 1. FT-IR spectra of $\mathrm{N}_{2}$

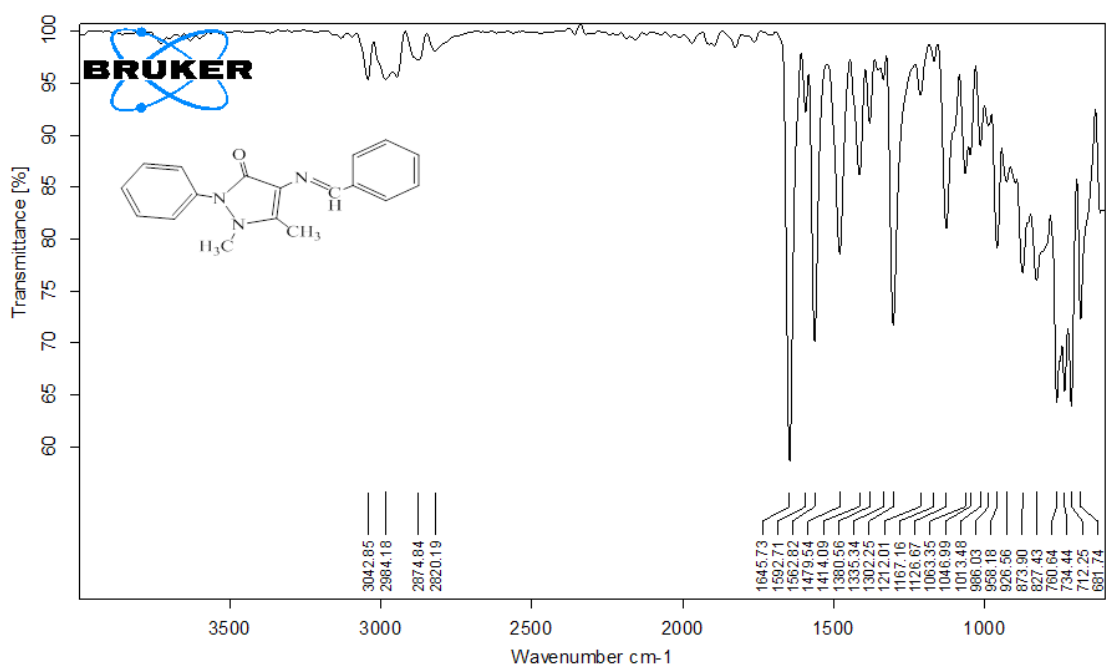

Figure 2. FT-IR spectra of $\mathrm{N}_{4}$

The mechanism of azomethine compounds formation was established by literature as given by Scheme 7. The reaction involves a nucleophile attack of the double-electronic of the $\mathrm{NH}_{2}$ group on the carbonyl group $\mathrm{C}=\mathrm{O}$ of aldehydes to form a hemiaminal $\mathrm{N}$-substituted medium that loses a water molecule to give the stable compound (azomethine). The reaction is believed to occur in the following mechanism $^{28}$ : 


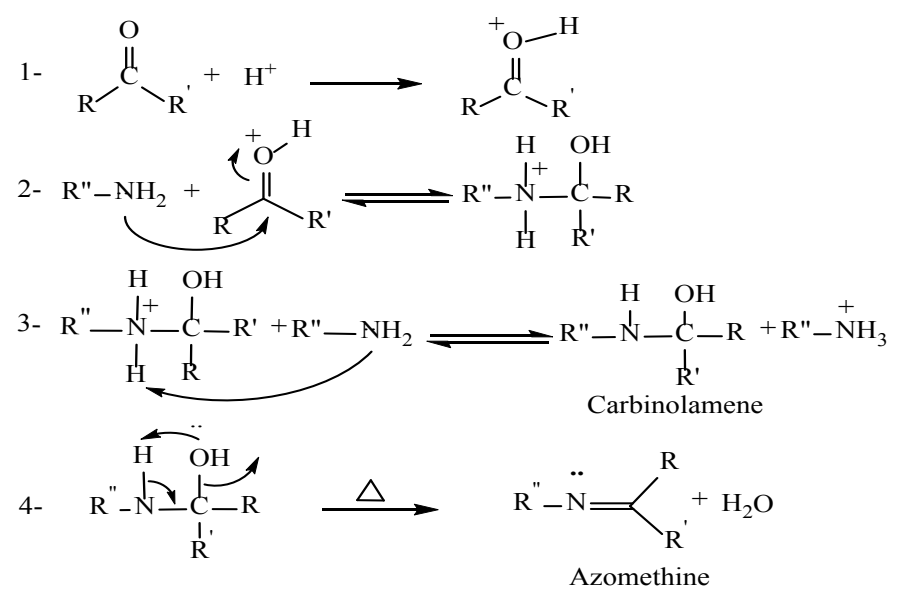

Scheme 7. Mechanism of azomethine compounds formation

The synthesis of oxazepine compounds was achieved by the reaction of imines and phthalide. The resulted products were identified by their melting points, FTIR spectra (Table 4) and both ${ }^{1} \mathrm{H}-\mathrm{NMR}$ and ${ }^{13} \mathrm{C}-\mathrm{NMR}$ spectral data (Table 5 \& 6). The FT-IR spectra of the products showed the disappearance of the stretching absorption bands of the group $(\mathrm{C}=\mathrm{N})$ of the azomethine compounds and the stretching absorption bands phthalide compound and showed the appearance of the stretching absorption bands at $1614-1650 \mathrm{~cm}^{-1}$ indicative of lactam bond $(\mathrm{C}=\mathrm{O})$ formation beside the characteristic bands of the residual groups in the structure, see Table 4 and Figure 3 and 4). ${ }^{27}$

Table 4. FT-IR of the prepared oxazepine compounds $\mathrm{N}_{6}-\mathrm{N}_{10}$

\begin{tabular}{|c|c|c|c|c|c|c|c|c|}
\hline \multicolumn{9}{|c|}{ FT-IR n $\left(\mathrm{cm}^{-1}\right)$} \\
\hline \multirow{2}{*}{$\begin{array}{l}\text { Comp. } \\
\text { Code }\end{array}$} & \multirow{2}{*}{$\begin{array}{c}\mathrm{C}=0 \\
\text { Lactam }\end{array}$} & \multirow{2}{*}{$\begin{array}{c}\text { C-0 } \\
\text { Lactam }\end{array}$} & \multirow{2}{*}{$\begin{array}{c}\text { C-N } \\
\text { Lactam }\end{array}$} & \multirow{2}{*}{$\begin{array}{l}\mathrm{C}=\mathrm{C} \\
\text { Arom }\end{array}$} & \multirow{2}{*}{$\begin{array}{l}\mathrm{C}-\mathrm{H} \\
\text { Arom }\end{array}$} & \multicolumn{2}{|c|}{ C-H Ali. } & \multirow{2}{*}{ Others } \\
\hline & & & & & & Asym. & Sym. & \\
\hline $\mathrm{N}_{6}$ & 1647 & 1112 & 1181 & 1603 & 3066 & 2962 & 2876 & $\begin{array}{c}\mathrm{NO}_{2} 1523 \\
1347\end{array}$ \\
\hline $\mathrm{N}_{7}$ & 1614 & 1134 & 1211 & 1586 & 3109 & 2987 & 2877 & $\begin{array}{c}\mathrm{O}-\mathrm{H} \text { b3497 } \\
\mathrm{N}-\mathrm{H} 3281 \\
\mathrm{NO}_{2} 1509, \\
1340\end{array}$ \\
\hline $\mathrm{N}_{8}$ & 1647 & 1108 & 1167 & 1576 & 3069 & 2943 & 2847 & $\begin{array}{c}\mathrm{NO}_{2} 1520 \\
1341\end{array}$ \\
\hline $\mathrm{N}_{9}$ & 1650 & 1130 & 1307 & 1567 & 3038 & 2944 & 2863 & -- \\
\hline $\mathrm{N}_{10}$ & 1643 & 1129 & 1289 & 1580 & 3042 & 2987 & 2890 & -- \\
\hline
\end{tabular}




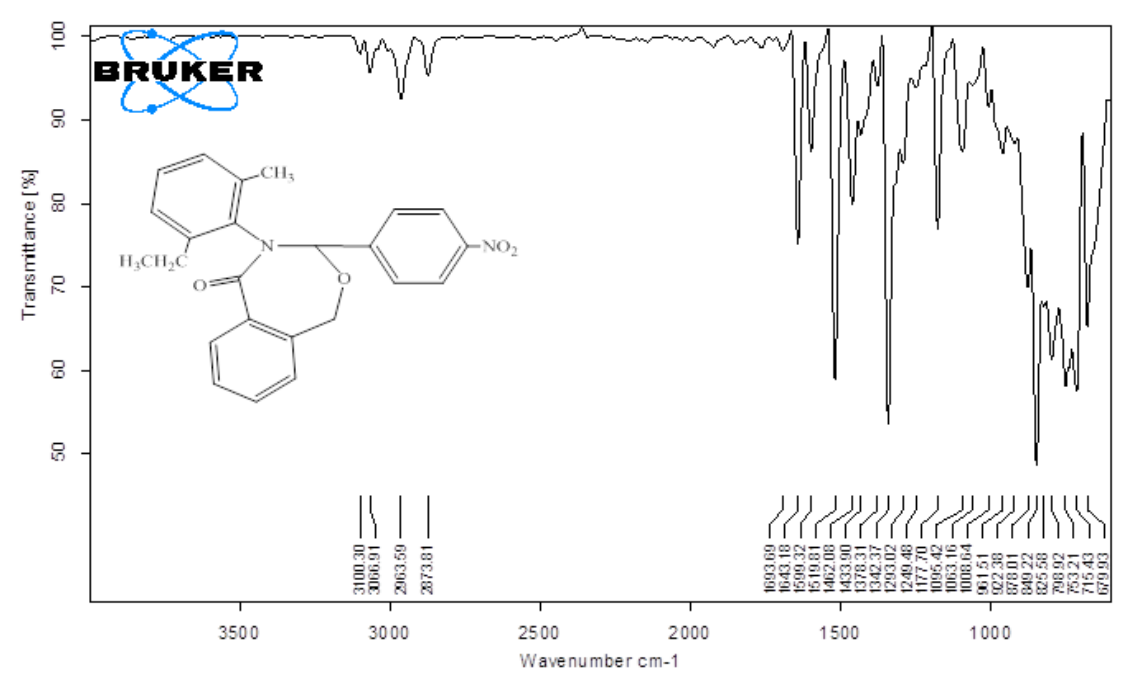

Figure 3. FT-IR spectra of $\mathrm{N}_{6}$

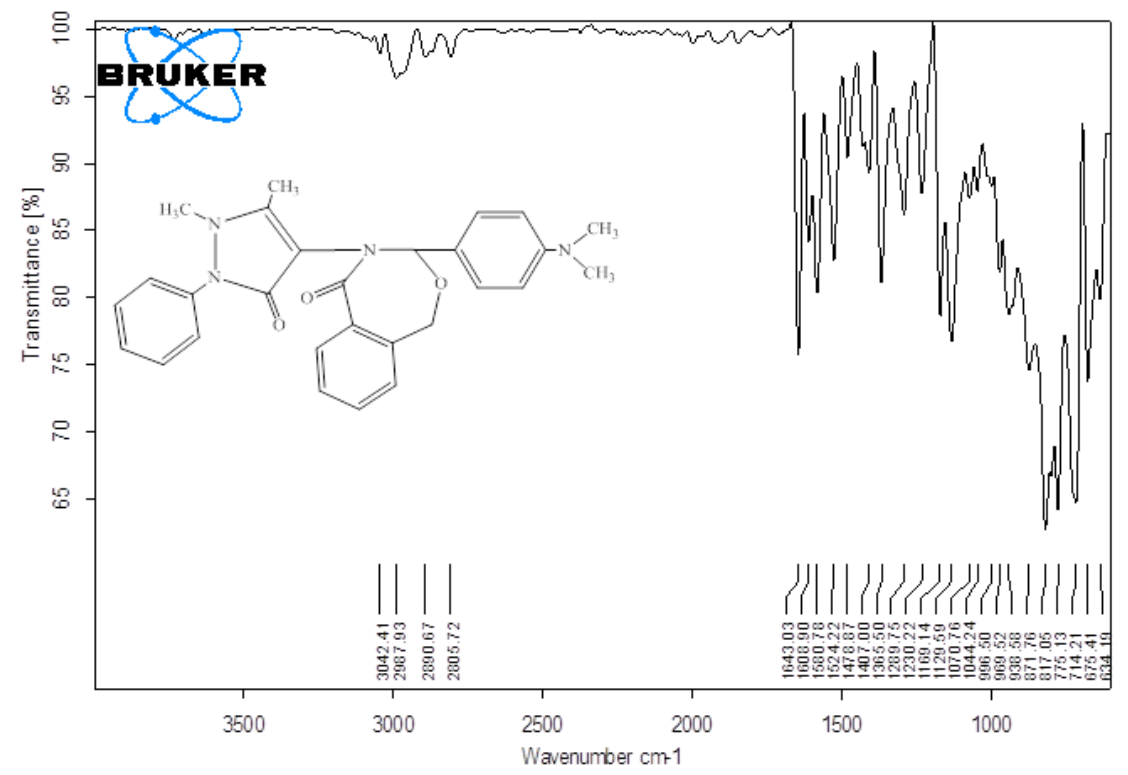

Figure 4. FT-IR spectra of $\mathrm{N}_{10}$ 
The ${ }^{1} \mathrm{H}-\mathrm{NMR}$ spectrum of compound $\mathrm{N}_{6}$ in solvent DMSO (Figure 5) showed chemical shifts, $\delta(\mathrm{ppm})$, triplet in $1.06\left(3 \mathrm{H}, \mathrm{CH}_{2}-\mathrm{CH}_{3}\right)$, singlet in $2.07(3 \mathrm{H}$, $\left.\mathrm{C}-\mathrm{CH}_{3}\right)$, quartet in $2.44\left(2 \mathrm{H}, \mathrm{CH}_{3}-\mathrm{CH}_{\underline{2}}\right)$, singlet in $3.18\left(2 \mathrm{H}, \mathrm{O}-\underline{\mathrm{CH}}_{2}\right)$, singlet in $8.55(\mathrm{H}, \mathrm{N}-\underline{\mathrm{CH}})$, multiplet and doublet of doublet in $8.42-6.98(11 \mathrm{H}$, aromatic protons) and spectrum of compound $\mathrm{N}_{7}$ (Figure 6) showed chemical shifts, $\delta(\mathrm{ppm})$ at: singlet in $3.31\left(3 \mathrm{H}, \mathrm{O}-\mathrm{CH}_{3}\right)$, singlet in $3.83\left(2 \mathrm{H}, \mathrm{O}-\underline{\mathrm{CH}}_{2}\right)$, singlet in $5.43(1 \mathrm{H},-\underline{\mathrm{NH}})$, singlet in $9.33(2 \mathrm{H}, \mathrm{N}-\underline{\mathrm{CH}})$, singlet in $11.57(1 \mathrm{H},-\underline{\mathrm{OH}})$, multiplet in 8.87-7.00 (13H,aromatic protons). ${ }^{28}$ Other chemical shifts, $\delta(\mathrm{ppm})$ of compounds $\mathrm{N}_{8}-\mathrm{N}_{10}$, are given in Table 5 .

Table 5. The ${ }^{1} \mathrm{H}-\mathrm{NMR}$ Spectra of the prepared oxazepine compounds $\mathrm{N}_{6}-\mathrm{N}_{10}$ in DMSO

\begin{tabular}{|c|c|}
\hline $\begin{array}{l}\text { Comp. } \\
\text { code }\end{array}$ & Chemical Shift $\delta$ ppm \\
\hline $\mathrm{N}_{6}$ & $\begin{array}{l}\text { Triplet in } 1.06\left(3 \mathrm{H}, \mathrm{CH}_{2}-\underline{\mathrm{CH}} 3\right) \text {, singlet in } 2.07\left(3 \mathrm{H}, \mathrm{C}-\underline{\mathrm{CH}_{3}}\right) \text {, quartet in } 2.44(2 \mathrm{H} \text {, } \\
\left.\mathrm{CH} 3-\underline{\mathrm{CH}_{2}}\right) \text {, singlet in } 3.18\left(2 \mathrm{H}, 0-\underline{\mathrm{CH}_{2}}\right) \text {, singlet in } 8.55(\mathrm{H}, \mathrm{N}-\underline{\mathrm{CH}}) \text {, multiplet and } \\
\text { doublet of doublet in } 8.42-6.98(11 \mathrm{H} \text {, aromatic protons). }\end{array}$ \\
\hline $\mathrm{N}_{7}$ & $\begin{array}{c}\text { Singlet in } 3.31\left(3 \mathrm{H}, 0-\mathrm{CH}_{3}\right) \text {, singlet in } 3.83\left(2 \mathrm{H}, 0-\mathrm{CH}_{2}\right) \text {, singlet in } 5.43(1 \mathrm{H} \text {, } \\
-\mathrm{N} \underline{\mathrm{H}}) \text {, singlet in } 9.33(\mathrm{H}, \mathrm{N}-\underline{\mathrm{C}} \underline{\mathrm{H}}) \text {, singlet in } 11.57(1 \mathrm{H},-\mathrm{O} \underline{\mathrm{H}}) \text {, multiplet in } 8.87-7.00 \\
(13 \mathrm{H} \text {,aromatic protons). }\end{array}$ \\
\hline $\mathrm{N}_{8}$ & $\begin{array}{c}\text { Singlet in } 1.18\left(3 \mathrm{H}, \mathrm{N}-\mathrm{CH}_{3}\right) \text {, singlet in } 2.51\left(3 \mathrm{H},=\mathrm{C}-\mathrm{CH}_{3}\right) \text {, singlet in } 3.39(2 \mathrm{H} \text {, } \\
\left.0-\underline{\mathrm{CH}}_{2}\right) \text {, singlet in } 9.67(\mathrm{H}, \mathrm{N}-\mathrm{CH}) \text {, multiplet and doublet of doublet in } 8.31-7.37 \\
(13 \mathrm{H} \text {, aromatic protons). }\end{array}$ \\
\hline $\mathrm{N}_{9}$ & $\begin{array}{l}\text { Singlet in } 1.24\left(3 \mathrm{H}, \mathrm{N}-\mathrm{CH}_{3}\right) \text {, singlet in } 2.47\left(3 \mathrm{H},=\mathrm{C}-\mathrm{CH}_{3}\right) \text {, singlet in } 3.19(2 \mathrm{H} \text {, } \\
\left.0-\underline{\mathrm{C}}_{2}\right) \text {, singlet in } 9.59(\mathrm{H}, \underline{\mathrm{N}}-\mathrm{C} \underline{\mathrm{H}}) \text {, multiplet in } 7.83-7.36(14 \mathrm{H} \text {, aromatic protons) }\end{array}$ \\
\hline $\mathrm{N}_{10}$ & $\begin{array}{l}\text { Singlet in } 1.23\left(6 \mathrm{H},-\mathrm{N}\left(\mathrm{CH}_{3}\right)_{2}\right) \text {, singlet in } 2.41\left(3 \mathrm{H}, \mathrm{N}-\mathrm{N}-\mathrm{CH}_{3}\right) \text {, singlet in } 2.98(3 \mathrm{H} \text {, } \\
\left.=\mathrm{C}-\mathrm{CH}_{3}\right) \text {, singlet in } 3.11\left(2 \mathrm{H}, 0-\mathrm{CH}_{2}\right) \text {, singlet in } 9.34(\mathrm{H}, \overline{\mathrm{N}}-\mathrm{CH}) \text {, multiplet and } \\
\text { doublet of doublet in } 7.64-6.74(13 \mathrm{H} \text {, aromatic protons). }\end{array}$ \\
\hline
\end{tabular}




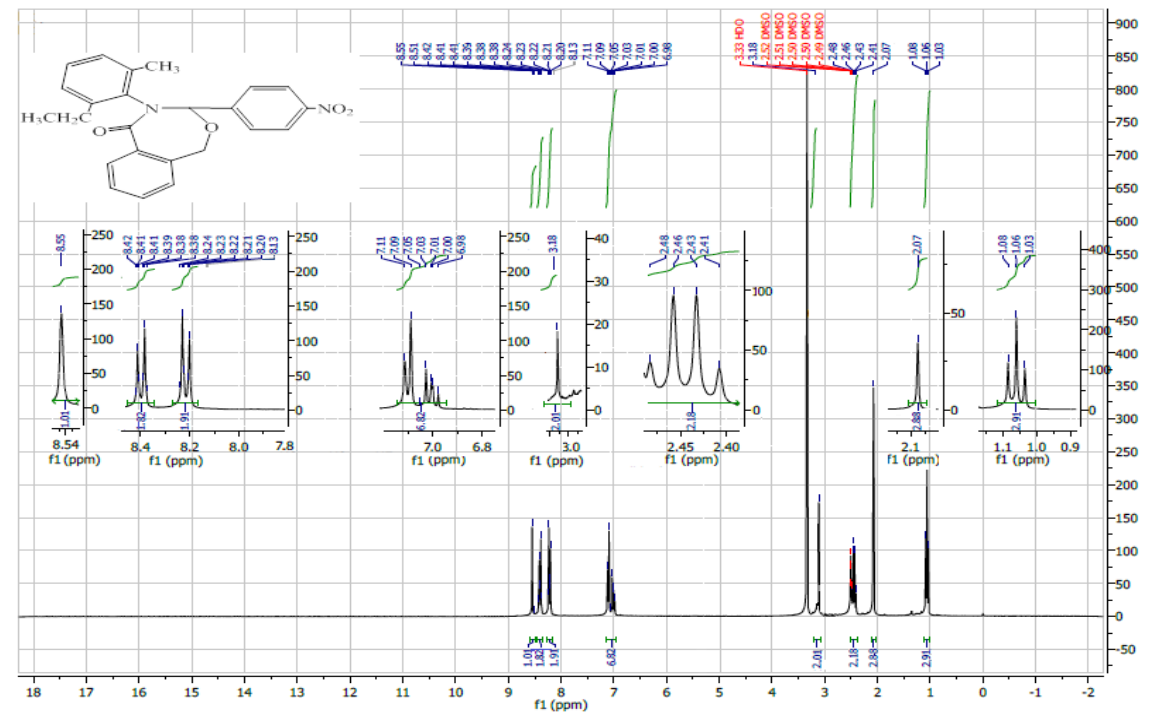

Figure 5. ${ }^{1} \mathrm{H}-\mathrm{NMR}$ Spectra of N6

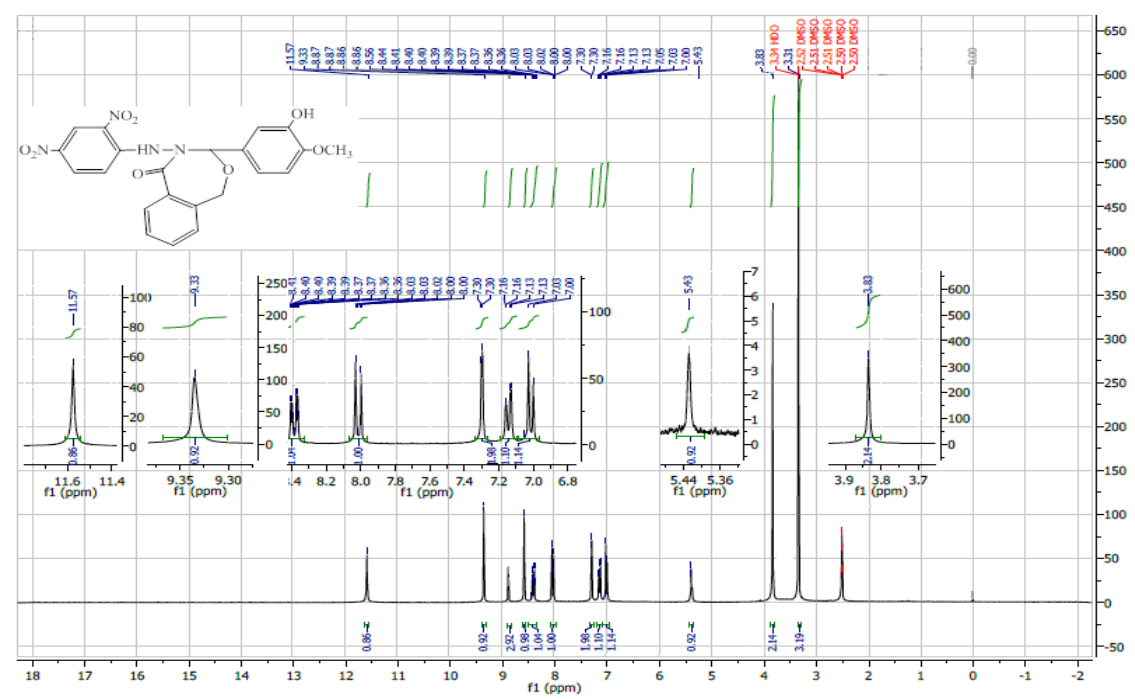

Figure 6. ${ }^{1} \mathrm{H}-\mathrm{NMR}$ Spectra of $\mathrm{N}_{7}$ 
The ${ }^{13} \mathrm{C}-\mathrm{NMR}$ spectrum of compound $\mathrm{N}_{6}$ in solvent DMSO (Figure 7) showed chemical shifts, $\delta(\mathrm{ppm}), 14.92\left(\mathrm{C}-\mathrm{CH}_{3}\right), 18.45\left(\mathrm{CH}_{2}-\mathrm{CH}_{3}\right), 24.60\left(\mathrm{CH}_{2}-\mathrm{CH}_{3}\right)$, $92.12\left(\mathrm{O}-\mathrm{CH}_{2}\right), 150.36(\mathrm{~N}-\mathrm{CH}), 162.20(\mathrm{~N}-\mathrm{CO}), 124.56-141.59$ (aromatic carbons) and spectrum of compound $\mathrm{N}_{7}$ (Figure 8 ) showed chemical shifts, $\delta(\mathrm{ppm})$, $25.58\left(\mathrm{O}-\underline{\mathrm{CH}}_{3}\right), 72.11\left(\mathrm{O}-\underline{\mathrm{CH}}_{2}\right), 147.35(\mathrm{~N}-\underline{\mathrm{C}} \mathrm{H}), 150.73(\mathrm{~N}-\underline{\mathrm{CO}}), 112.34-137.04$ (aromatic carbons) ${ }^{29}$. Other chemical shifts, $\delta(\mathrm{ppm})$ of compounds $\mathrm{N}_{8}-\mathrm{N}_{10}$, are given in Table 6.

Table 6. The ${ }^{13} \mathrm{C}-\mathrm{NMRR}$ Spectra of the prepared oxazepine compounds $\mathrm{N}_{6}-\mathrm{N}_{10}$ in DMSO

\begin{tabular}{|c|c|}
\hline $\begin{array}{l}\text { Comp. } \\
\text { code }\end{array}$ & Chemical Shift $\delta \mathrm{ppm}$ \\
\hline $\mathrm{N}_{6}$ & $\begin{array}{c}\left.14.92(\mathrm{C}-\underline{\mathrm{CH}})_{3}\right), 18.45\left(\mathrm{CH}_{2}-\underline{\mathrm{CH}}_{3}\right), 24.60\left(\underline{\mathrm{CH}}_{2}-\mathrm{CH}_{3}\right), 92.12\left(\mathrm{O}-\underline{\mathrm{CH}}_{2}\right), 150.36(\mathrm{~N}-\underline{\mathrm{CH}}), \\
162.20(\mathrm{~N}-\underline{\mathrm{C}}), 124.56-141.59 \text { (Aromatic Carbons). }\end{array}$ \\
\hline $\mathrm{N}_{7}$ & $\begin{array}{c}25.58\left(0-\underline{C H}_{3}\right), 72.11\left(0-\underline{C H}_{2}\right), 147.35(\mathrm{~N}-\underline{\mathrm{CH}}), 150.73(\mathrm{~N}-\underline{\mathrm{CO}}), 112.34-137.04 \\
\text { (Aromatic Carbons). }\end{array}$ \\
\hline $\mathrm{N}_{8}$ & $\begin{array}{c}10.17\left(\mathrm{~N}-\underline{\mathrm{C}} \mathrm{H}_{3}\right), 35.41\left(=\mathrm{C}-\underline{\mathrm{C}} \mathrm{H}_{3}\right), 99.14\left(\mathrm{O}-\underline{\mathrm{C}} \mathrm{H}_{2}\right), 144.03(\mathrm{~N}-\underline{\mathrm{C}} \mathrm{H}), 148.21\left(\mathrm{CH}_{3}-\underline{\mathrm{C}}=\right), \\
151.22(\mathrm{CO}-\underline{\mathrm{C}=}), 152.83(\mathrm{~N}-\underline{\mathrm{C}} \mathrm{O} \text { in the five-membered ring), } 159.41(\mathrm{~N}-\underline{\mathrm{CO}} \text { in the } \\
\text { seven-membered ring), 116.05-129.69 (Aromatic Carbons). }\end{array}$ \\
\hline $\mathrm{N}_{9}$ & $\begin{array}{c}10.24\left(\mathrm{~N}-\underline{\mathrm{CH}}_{3}\right), 35.83\left(=\mathrm{C}-\underline{\mathrm{CH}}_{3}\right), 93.62\left(0-\underline{\mathrm{CH}}_{2}\right), 145.04(\mathrm{~N}-\underline{\mathrm{CH}}), 147.99\left(\mathrm{CH}_{3}-\underline{\mathrm{C}}=\right), \\
152.69(\mathrm{CO}-\mathrm{C}=), 154.80(\mathrm{~N}-\mathrm{C} O \text { in the five-membered ring), } 160.07(\mathrm{~N}-\underline{\mathrm{C} O} \text { in the } \\
\text { seven-membered ring), } 116.60-130.63 \text { (Aromatic Carbons). }\end{array}$ \\
\hline $\mathrm{N}_{10}$ & $\begin{array}{c}\text { singlet in } 10.31\left(-\mathrm{N}\left(\mathrm{CH}_{3}\right)_{2}\right) \text {, singlet in } 36.26\left(\mathrm{~N}-\mathrm{N}-\mathrm{CH}_{3}\right), 38.08\left(=\mathrm{C}-\mathrm{CH}_{3}\right), 98.12 \\
\left(0-\mathrm{CH}_{2}\right), 135.11(\mathrm{~N}-\mathrm{CH}), 151.77\left(\mathrm{CH}_{3}-\mathrm{C}=\right), 152.19(\mathrm{CO}-\mathrm{C}=), 155.87(\mathrm{~N}-\mathrm{CO} \text { in the } \\
\text { five-membered ring), } 160.07 \text { ( } \mathrm{N}-\mathrm{CO} \text { in the seven-membered ring), } 118.05-129.52 \\
\text { (Aromatic Carbons). }\end{array}$ \\
\hline
\end{tabular}




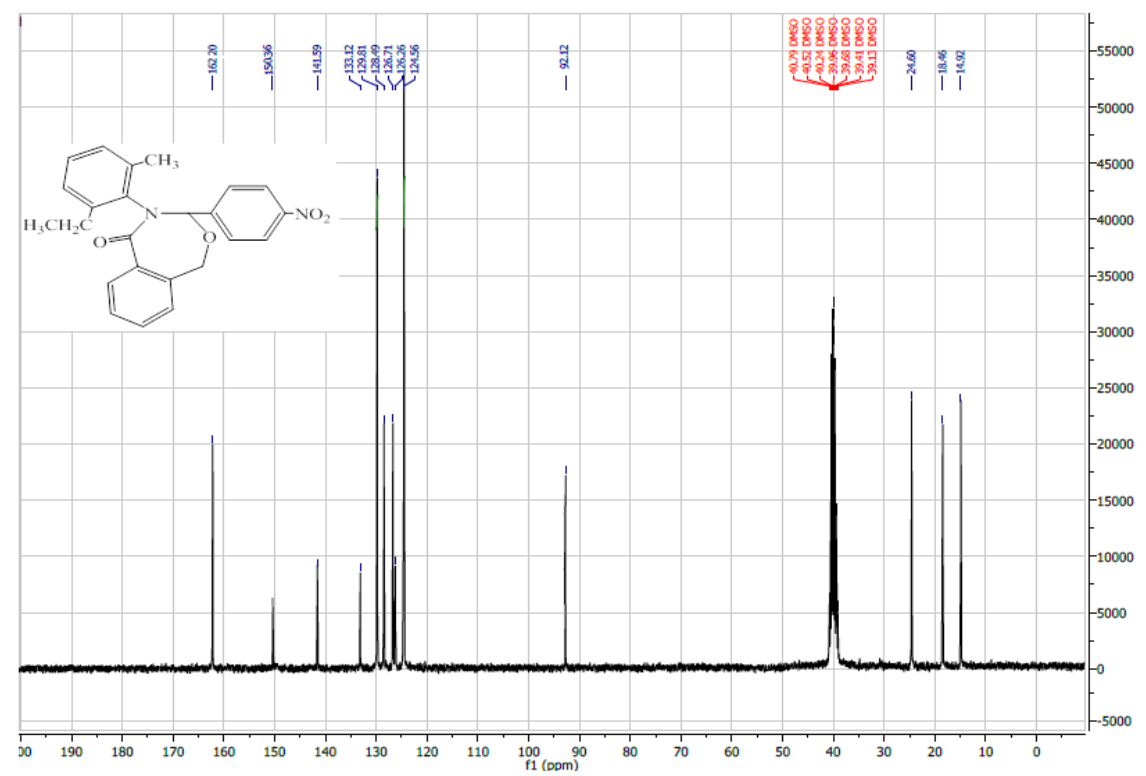

Figure $7 .{ }^{13} \mathrm{C}$-NMR Spectra of $\mathrm{N}_{6}$

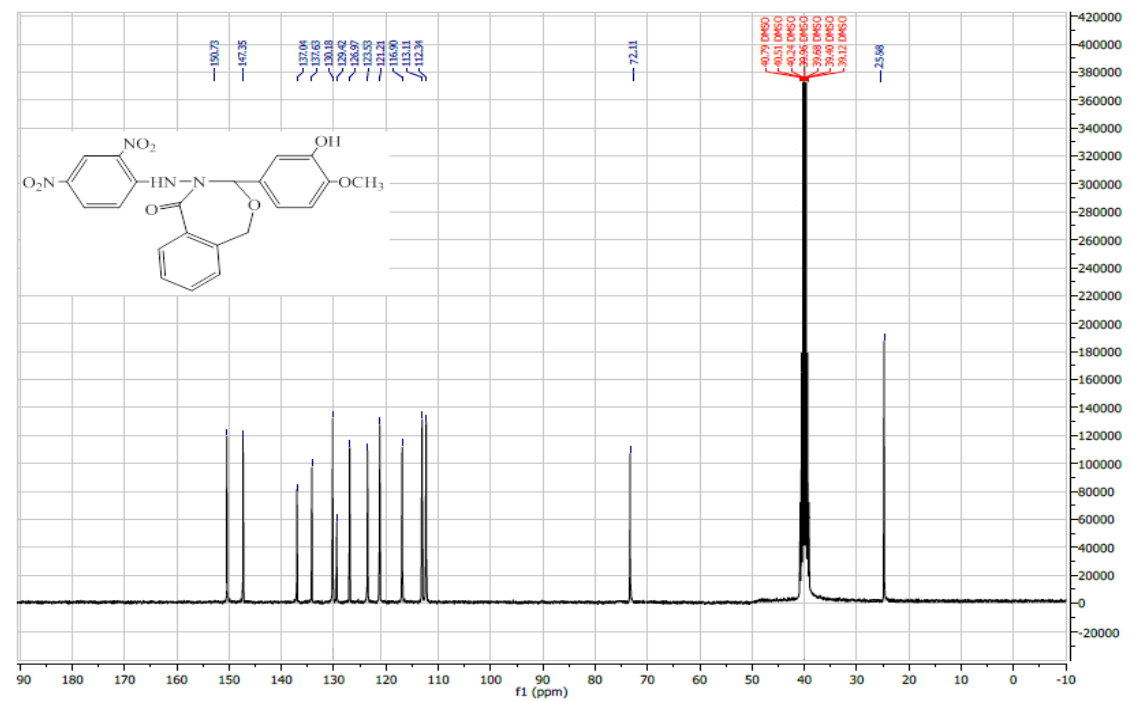

Figure $8 .{ }^{13} \mathrm{C}$-NMR Spectra of $\mathrm{N}_{7}$ 
The reaction of the prepared azomethine compounds with phthalide is given in the following equation (Scheme 8). Glacial acid is used as a catalyst to increase the electrophile of the carbonyl group of phthalide compound to accelerate the reaction and direct the reaction toward the carbon of carbonyl in the fivemembered ring of phthalide compound rather than toward the methylene group $\left(\mathrm{CH}_{2}\right)$ at the same ring of phthalide compound. ${ }^{30}$

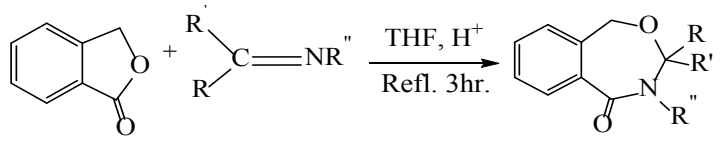

$\mathrm{R}^{\prime}=\mathrm{H}$

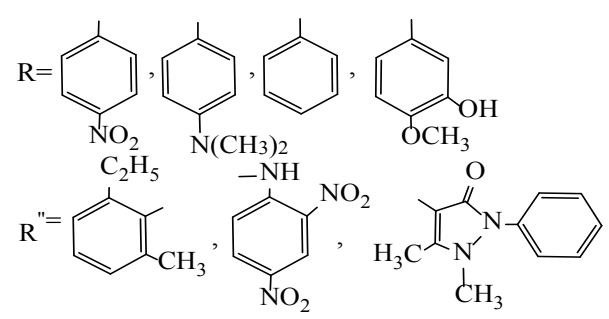

Scheme 8. Structure of the prepared oxazepine compounds

It may be concluded that the reaction takes places via concerted $\left(5^{+2}\right)$ dipolar cycloaddition mechanism as represented in the reaction Scheme 9. ${ }^{30,31}$

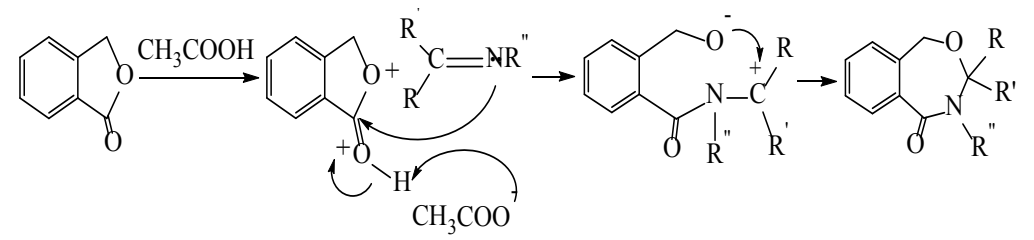

Scheme 9. Mechanism of oxazepine compounds formation

The reaction involves a nucleophile attack of the double-electronic of the azomethine group at the electropositive carbon atom of the carbonyl group to give a dipolar intermediate and the target molecule of oxazepine compounds.

\section{Antifungal activity}

Zone of inhibition of some human pathogenic fungi was done well-diffusion method to test the potential of the prepared oxazepine compounds $\mathrm{N}_{6}-\mathrm{N}_{9}$ as shown in Figure 9. Generally, $\mathrm{N}_{9}$ is the best derivative that has significantly ( $p<0.01$ ) recorded a stronger influence to inhibit the growth of Candida sp. at an average of the zone of inhibition $13.8 \mathrm{~mm}$, while $\mathrm{N}_{7}$ derivative has recorded the lowest inhibition $10.9 \mathrm{~mm}$ toward clinical fungal pathogens. From another hand, $\mathrm{N}_{9}$ and $\mathrm{N}_{7}$ derivatives have recorded the higher zone of inhibition $15 \mathrm{~mm}$ 
against Candida guilliermondii and Candida zeylanoides respectively followed $14 \mathrm{~mm}$ by $\mathrm{N}_{9}$ toward Candida albicans. N8 and N6 derivatives have shown inhibitory effects $13.3 \mathrm{~mm}$ and $13.0 \mathrm{~mm}$ against growth of Candida krusei and Candida guilliermondii respectively. The lower zone of inhibition was $8.0 \mathrm{~mm}$ and $9.3 \mathrm{~mm}$ y $\mathrm{N}_{7}$ toward the growth of Candida albicans and Candida guilliermondii respectively (see Figure 10). Ahmed et al. studied antibacterial activity of 1,3-oxazepine and 1,3,4-oxadiazole ${ }^{32}$, while Sunil et al. studies role of oxazepine derivative as an anticancer agent against Human Colorectal Adenocarcinoma. ${ }^{33}$ The resistance mechanisms depend on which specific pathways are inhibited by the drugs and the alternative ways available for those pathways that the organisms can modify to get a way around to survive. ${ }^{34}$

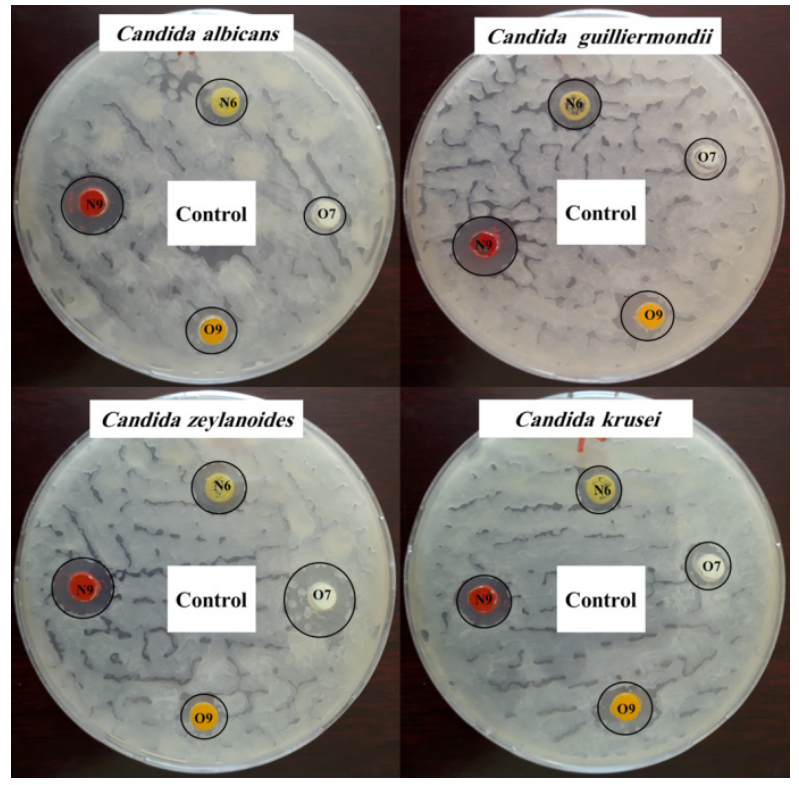

Figure 9. Antifungal activity of the prepared oxazepinecompounds $\mathrm{N}_{6}-\mathrm{N}_{9}$ in methanol 


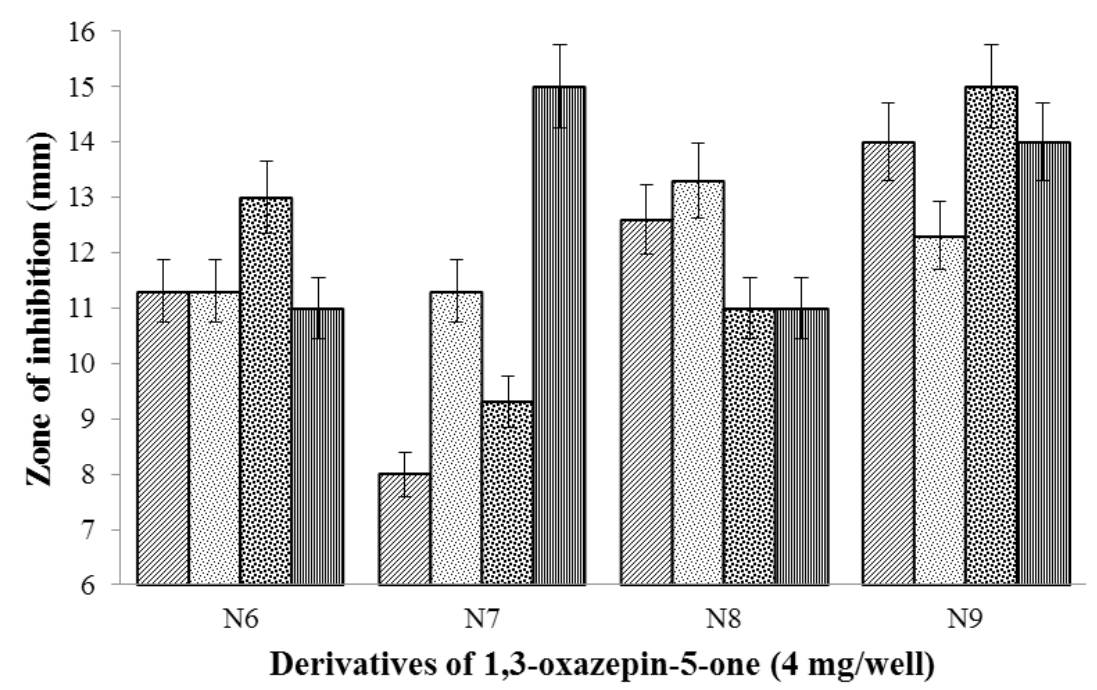

Figure 10. Zone of inhibition of Candida sp. using the prepared oxazepine compounds ( $\mathrm{mm}$ )

\section{CONCLUSION}

The formation of stable 7 th-membered 1,3- oxazepine ring has been achieved by $(5+2)$ cycloaddition reaction of phthalic and azomethine group. The results of FT-IR, ${ }^{13} \mathrm{C}-\mathrm{NMR}$, and ${ }^{1} \mathrm{H}-\mathrm{NMR}$ showed that the target molecules were formed due to the least obstructive effect in all preparation processes. Generally, $\mathrm{N}_{9}$ is the best derivative that has significantly $(p<0.01)$ recorded a stronger influence to inhibit growth of Candida sp. at average of zone of inhibition $13.8 \mathrm{~mm}$, while $\mathrm{N}_{7}$ derivative has recorded the lowest inhibition to clinical fungal pathogens $(10.9 \mathrm{~mm})$. Slight variation in the structure of those derivatives can show the very dramatic effect on the efficiency of these compounds in their bio-activity. The present work may be helpful in designing more potential antibacterial and antifungal agents for therapeutic use in the future.

\section{ACKNOWLEDGEMENTS}

The authors are thanking staff of Department of Chemistry, College of Science, University of Anbar for achieving this work in well. Also, they are grateful for Al-Mustafa Laboratory in Hit, Iraq for helping to complete the bioactivity tests and for Dr. Rusol Al-Bahrani for obtaining the Candida isolates from College of Science, University of Baghdad, Iraq. 


\section{REFERENCES}

1. K Brodowska and E Chruścińska. Schiff bases - interesting range of applications in various fields of science. CHEMIK, 2014, 68, 129-134.

2. W Qin, S Long, M Panunzio and S Biondi. Schiff Bases: A Short Survey on an Evergreen Chemistry Tool. Molecules 2013, 18, 12264-12289.

3. A Adabiardakani, M Hakimi and H Kargar. Cinnamaldehyde Schiff Base Derivatives: A Short Review. WA P journal 2012, 2, 472-476.

4. A Ashraf, K Mahmood and A Wajid. Synthesis, Characterization and Biological Activity of Schiff Bases. IPCBEE 2011, 1O, 1-7.

5. Z Hussain, Z Fadhil, H Adil, M Khalaf, B Abdullah and E Yousif. Schiff's Bases Containing Sulphamethoxazole Nucleus. RJPBCS 2016, 7(3), 1500-1510.

6. T Helal, G Abbas and F Mohammed. Synthesis and Identification of new 4-Aminophenazone derivatives containing azo group. IJMRD 2014, 1, 41-45.

7. V Desai and R Shinde. Green Synthesis of Nicotinic Acid Hydrazide Schiff Bases And Its Biological Evaluation. Int J Pharm. 2015, 5, 930-935.

8. Z Salim, I Hameed and A Hussein. Synthesis and Characterization of New AminoAcidSchiff Bases and Studies their Effects on the Activity of ACP, PAP and NPA Enzymes (In Vitro). EJCHEM, 2102, 9, 962-969.

9. N Al-Jamali, M Jameel and A Al-Haidari. Preparation And Invitigation Of Diazipene, Oxazipen Compounds Through Condensation Reaction. Innovare Journal of Science 2013, 1, 13-15.

10. A Khan, I Raoof and H Essa. Synthesis, Characterization of Some New Azo CompoundsContaining 1,3-Oxazepine, Anthraquinone Moieties and Studying Their Activity against Pathogenic Bacteria. Journal of Natural Sciences Research, 2015, 5, 69-80.

11. R Haiwal. Synthesis of Novel 1, 3 -Oxazepine Compounds from New Azo Schiff bases Containing Thiadiazole Moiety. Scientific Journal of Kerbala University 2011, 9, 96-111.

12. OH Abid, RF Muslim and KM Mohammed. Synthesis and Characterization of Novel 1,3,4,9a-Tetrahydrobenzo[ $e][1,3]$ oxazepin- $5(5 \mathrm{a} H)$-one Derivatives via Cycloaddition Reactions of Schiff Bases. Journal of University of Al-Anbar for Pure Science 2016, 10, 8-18.

13. A Younus and N Jaber. Synthesis and Characterization a New 1,3-Oxazepine Compounds from New Bis-4-Amino-3-mercapto-1,2,4-triazole Derivatives. Organic Chemistry: An Indian Journal 2016, 12, 1-12.

14. H Sabah. Synthesis, spectroscopic characterization of schiff bases derivedfrom 4,4'-methylen di aniline. Der Pharma Chemica 2014, 6, 38-41.

15. R Al-Juburi. Synthesis and Characterization of Some Heterocyclic Compounds (Oxazepine, Tetrazole) Derived from Schiff Bases. Journal of Al-Nahrain University 2012, 15, 60-67.

16. MY Nassar, IS Ahmed, HA Dessouki and SS Ali. Synthesis and characterization of some Schiff base complexes derived from 2, 5-dihydroxyacetophenone with transition metal ions and their biological activity. Journal of Basic and Environmental Sciences 2018, 5, 60-71.

17. MM El-ajaily1, AA Maihub, UK Mahanta, G Badhei, RK Mohapatra and PK Das. Mixed ligand complexes containing schiff bases and their biological activities: a short review. Rasayan J. Chem. 2018, 11, 166-174. 
18. C Nastasa, DC Vodnar, I Ionu, A Stana, D Benedec, R Tamaian, O Oniga and B Tiperciuc. Antibacterial Evaluation and Virtual Screening of New Thiazolyl-Triazole Schiff Bases as Potential DNA-Gyrase Inhibitors, Int. J. Mol. Sci. 2018, 19, 1-18.

19. JN Bavane and RB Mohod. Synthesis, characterization and electrochemical studies of symmetrical schiff base complexes of [1-(5 chloro-2-hydroxy-4-methyl- phenyl) ethanone-4-chloro (-3-trifluro methyl) aniline]. The Pharma Innovation Journal 2018, 7, 149-152.

20. K Al-Sultani. Synthesis, identification and evaluation tha biological activity for some new heterocyclic compoundsderived from Schiff bases. IOSR Journal of Applied Chemistry 2016, 9, 01-11.

21. A Yasir and H Mohammed. Synthesis of New Heterocyclic Derivative [4-(2-Phenyl-2,3-Dihydrobenzo-1,3-Oxazipine-4,7-Dione)Benzaldehyde]. Int. J. Adv. Res. 2o17, 5, 170-175.

22. H Sadiq. Synthesis And Characterization of Novel 1,3-Oxazepine Derivatives From Aminopyrazine. World Journal of Pharmacy and Pharmaceutical Sciences 2017, 6, 186-198.

23. A Yasir. Synthesis of New Heterocyclic Derivative 1,3-Oxazepine From Schiff Base Benzylidenehydrazine. MJPS, 2016, 3, 1-5.

24. K Mohammad, M Ahmed and M Mahmoud. Synthesis and characterization of some new (1,3-Oxazepine) derivative from 6-methyl 2-thiouracil and study their biological activity. Tikrit Journal of Pure Science 2017, 22, 67-81.

25. M Kadhim and H Ghanim, Synthesis And Identification 1-3 Diazepine From Ibuprofen, International Journal of Scientific \& Technology Research 2014, 3, 213-217.

26. MN Owaid, J Raman, H Lakshmanan, SSS Al-Saeedi, V Sabaratnam and IAA Al-Assaffii. Mycosynthesis of silver nanoparticles from Pleurotus cornucopiae var. citrinopileatus and its inhibitory effects against Candida sp. Materials Letters 2015, 153, 186-190.

27. J Simek. Organic Chemistry. 8th edition, Pearson education, Inc., 2013, p. 412-414.

28. R Silverstein, F Webster and D Kiemle. Spectrometric identification of organic compounds. 7th edition, John Wiley and sons, Inc., 2005, p. 72-126.

29. B Mistry, A Handbook of spectroscopic Data chemistry. Oxford book company Jaipor India, Mehra Offset Printers, Delhi, 2009, p. 99-127.

30. OH Abid, HM Tawfeeq and RF Muslim. Synthesis and Characterization of Novel 1,3-oxazepin-5(1H)-one Derivatives via Reaction of Imine Compounds with Isobenzofuran-1(3H)-one. Acta Pharm. Sci. 2017, 55, 43-55.

31. OH Abid, RF Muslim and KM Mohammed. Synthesis and Characterization of Novel 1,3-oxazepin-4-ones derivatives via Schiff Bases Reactions with Phthalide $J$. of University of Al-Anbar for pure science 2016, 1O, 1-9.

32. A Ahmed, S Mahdi, A Hussein, A Hamed, E Yousif. Antibacterial Study of Some Oxazepine Derivatives. Journal of Al-Nahrain University 2015, 18, 22-26.

33. D Sunil, C Ranjitha, M Rama and Pai KSR. Oxazepine Derivative as an Antitumor Agent and Snail1 Inhibitor against Human Colorectal Adenocarcinoma. International Journal of Innovative Research in Science, Engineering and Technology 2014, 3, 15357-15363.

34. FC Tenover. Mechanisms of antimicrobial resistance in bacteria. Am. J. Med. 20o6, 119, 3-10. 
